\title{
CULTURAL MINORITIES AND THE PANOPTIC GAZE: A STUDY OF THE (MIS)REPRESENTATION OF ETHNIC MINORITIES IN MALAYALAM FILMS
}

\author{
R. V. M. DIVAKARAN \\ Dept. Of Malayalam, University Of Calicut, Kerala, India 673635 \\ E-mail address: rvmdivakaran@gmail.com
}

\begin{abstract}
This paper explores the patterns of the representation of Adivasis or aboriginals - known as 'tribals' in common parlance - in Malayalam language films. Film as a medium of representation is continuously engaged in constructing images and thus the process becomes an ideological enterprise contributing to the relentless practice of defining and redefining the society and its various components in terms of several binaries. The film industry of Kerala, a southern state of India, is affluent and more influential than other art forms and production. Though the tribal population of Kerala is around 400 thousand and they belong to as many as 43 subgroups, they are underrepresented in films and that too is in a stereotypical manner. These groups are considered to be largely distinct with each tribal group identifying themselves with their own mythologies, tales of origin, and distinctive religious and ritualistic practices. This paper critically analyses the politics of representation using the example of tribals in Malayalam films as it has evolved over the past decades and attempts to trace a whole gamut of aesthetic and ethical issues at stake.
\end{abstract}

Keywords: Representation, aboriginal, tribes, Film, Gaze

\section{INTRODUCTION}

Film as a medium of representation is actively involved in constructing images of people, places, beliefs and ideas. Needless to say, media representation is an ideological enterprise contributing to the incessant process of defining and redefining the society and its various components in terms of several binaries. This paper examines how the popular films represent ethnic minorities and how they create a representational image of a cultural minority flattening all vast diversities of subcultures and identities into one generic stereotype. The filmdom of Kerala, a southern state of India, is a flourishing industry that produces an average of 150 films per year. It has won global recognition for its artistic merits and thematic experiments. This paper explores the patterns of the representation of adivasis, or aboriginals - known as 'tribals' in common parlance - in Malayalam films. 


\section{LOOKING AT TRIBALS}

Tribal, as a noun, is a term coined by the British colonizer to denote the tribes in South Asia, and how they are characterized by tribal origin, their primitive way of life, remote habitation, and general backwardness in all regions. The term Adivasi literally means primitive (adi) inhabitants (vasi), or inhabiting or existing in a land from the earliest times or from before the arrival of colonists. According to anthropologist Dhirendra Nath Majumdar, a tribe is a social group with territorial affiliation, endogamous, with no specialization of functions, ruled by tribal officers, hereditary or otherwise, united in language or dialect, recognizing social distance with other tribes or castes, without any social obloquy attached to them, as it does in the caste structure, follows tribal traditions, beliefs and customs, illiberal of naturalization of ideas from alien sources, above all conscious of homogeneity of ethnic and territorial integration. It has a common name, the members of which occupy the same territory, speak the same language and observe certain taboos, regarding marriage, professions and has developed a well assured system of reciprocity and mutuality of obligations (Majumdar, 1961, p. 367).

The tribal population of Kerala is around 400 thousand and they belong to as many as 43 sub-groups 9 . These groups are considered to be largely distinct with each tribal group identifying themselves with their own mythologies, tales of origin, and distinctive religious and ritualistic practices. In terms of developmental indices and health standards, the tribal populations in the State lag way behind other sections of the Kerala society.

Since the exotic and the alien always hold fascination for the scopophilic public, the Malayalam film industry has from its early days tried to depict tribal life in its various manifestations. The word scopophilia, referring to a kind of visual pleasure, is often used by cinema psychoanalysts to describe pleasures and certain unconscious processes occurring in spectators when they watch films. Words like voyeurism and the male gaze are also seen as central elements in the analysis of such mainstream cinematic viewing. It refers to the predominant male gaze of the cinema which enjoys objectifying women into mere objects to be looked at- in her seminal essay, Visual Pleasure and Narrative Cinema, Laura Mulvey calls it 'to-be-looked-at-ness' (1993, p. 309). Moreover, the scopophilic gaze is fetishistic and sees them as beautiful objects of display and also represents women as powerless and insignificant. It signifies a psychological relationship of power, in which the gazer is always superior to the object of the gaze. Coming to the term panoptic gaze, the power relation becomes more evident and the spectator identifies his position as that of the surveillant though he himself falls in a position of object to be watched at through the technological apparatus.

The Panopticon was a kind of prison, designed to leave the prisoner a subject to constant observation. The surveillants believe that this surveil-

9 Govt. of India (nd.). Report of the Ministry of Tribal Affairs. Retrieved on 20 March 2017 from: http://tribal.nic.in/ST/LatestListofScheduledtribes.pdf, p.5. 
lance would prevent those objects from doing anything wrong or harmful. The convict who feared being watched may abstain from behaviour he/she might otherwise engage in if no one was around to see. In mainstream film the mechanism of panoptic gaze creates an object of pleasure which behaves consonantly to the expectations of the spectator who identifies himself/ herself as surveillant. The cinematic apparatus itself acts as a normalizing mechanism which constantly provides instances of deviations. Michel Foucault $(1979$, p. 217) believes that we have already internalized a gaze of the other and integrated it into our own subjectivity to such a degree that there is no longer a need for any surveilling person to uphold the social system. He argues that our society is not one of spectacle but of surveillance. Spectators are neither in an amphitheatre, nor on the stage, but in the panoptic machine, invested by its effects of power, which we bring to ourselves, since we are part of its mechanism. The depiction of tribes in Malayalam film clearly states this objectifying, fetishistic and normalizing gaze, which has already created a stereotypical image of the aboriginals as a whole. The process of stereotyping racial and ethnic minorities demands an imagological analysis as well. While conceptualizing Imagology, comparatist Joep Leerssen (2016, p. 22) explains how the auto and hetero imaging mechanism works in popular media. He points out the example of the film Casablanca (Curtiz, 1942) which brings refugee actors from various European nations together in a Hollywood studio to play refugee characters from various European nations, reemphasizing the ethnotypes like rakish Frenchman, bloody-minded German, tough American etc.

\section{STEREOTYPES AND TROPES}

Malayalam cinema from its early days sporadically tried to include one or more tribal characters as part of a cultural mix as evident in its first jungle movie Vanamaala (G. Viswanathan, 1951; see Pillai, 1970, p. 147). In certain films heroes and heroines go for an outing into the wilds and these tribal people help them in lovemaking by singing and dancing around them. Protagonists can easily acquire an extra charm by displaying these 'uncivilized' rough strokes in the backdrop. In another set of films tribals rescue the hero in a crucial moment by giving some tribal medicine and magically healing him from a pernicious situation. In most of the films featuring tribals as characters, they are somehow sidelined for their otherness.

There are more than a dozen films that primarily focus on the tribal experience in Malayalam. Films like Nellu (Ramu Karyat, 1974), Picnic (J. Sasikumar, 1975), Ponni (Thoppil Bhasi, 1976), Malamukalile Daivam (P. N. Menon, 1983), Uyarum Nhan Nadake (P. Chandra Kumar, 1985), Chithram (Priyadarshan, 1988), Bamboo Boys (Ali Akbar, 2002) and Photographer (Ranjan Pramod, 2006) are prominent among them. Some of these films portray the tribal people as subhuman by highlighting their lack of hygiene, loose sexual mores, and mis- 
erable living conditions, and other films glamourise them for the sake of visual pleasure for the non-tribal spectatorship. Their typical physical features which include darker complexions and stunted height are also used to encode their inferior status. Some of the films, like Ponni, even tap into the Hollywood trope of a wicked and bloodthirsty savage to stereotype tribal people, very much in the cast of the dreaded and hated Native Americans.

The first notable Malayalam film that dealt with tribal's issues was Nellu (Ramu Karyat, 1974). It was an adaptation of the novel of the same title written by P. Valsala. Some of the early films like Vanamaala (G. Viswanathan, 1951), Aana Valarthiya Vanampadi (P. Subramaniyam, 1959), Kaattu Maina (M. Krishnan Nair, 1963), Kaattu Mallika (P. Subramaniyam, 1966) had the jungle as its backdrop. But Nellu, was the first one to portray the life of the adivasis of the State. The film deals with the unique customs, manners, beliefs, taboos and prejudices of the Adiyar tribal community in Wayanad and was shot almost entirely in the same district. This film exploited the scenic beauty of the hilly area by the excellent camera work by Balu Mahendra, a noted director and cinematographer of south India and created a romantic concept about the life of adivasis. Beautiful musical scores and four songs composed by Salil Chowdhary, one of the best composers in India, became instrumental for setting up some basic ingredients for the forthcoming movies with similar patterns. Most of the tribal films tried to include at least half a dozen song/dance sequences in the content mix. Nellu also lined up a set of major actors of that time. The evergreen superstar Prem Nazir, a world record holder for playing the lead role in 725 films, comes in the central role as an upper caste young man coming to the tribal village as part of his pilgrimage to a forest temple. He comes across the life of the tribals and witnesses their struggle against rough weather and wild nature, their superstitions, various kinds of exploitations they face and he notes down every single detail in his diary. The film progresses through his point of view.

The story line, which covers some of their customs and beliefs, is very interesting. A handsome tribal youth Mallan loves a tribal girl Mara deeply but unfortunately, being in the same clan they were not allowed to marry. The tribal chief imposes a ban on their marriage, but the lovers run away violating all the customs to live together. The entire community turns against them and a huge penalty is imposed on them for their mistake. Mallan leaves the village to earn the money to pay off the penalty and during his absence Mara was kept in a house outside the tribal settlement. During her stay there she was raped by the man in that house. As she loses her virginity, her lover becomes ill and at last he somehow comes back with the money only to woo his death. Our protagonist saves the lonely girl from the tribal community and she is handed over to a non tribal widow and she accepts her as her daughter. After this successful intervention our hero leaves the village.

It is striking to note that the first notable tribal film in Malayalam narrates the story from an outsider's perspective. As a result of this alien gaze, tribal customs and beliefs turn superstitious and awkward. The film underlines the 
mediation of an educated cultured outsider to correct them and thus leaves an anti-tribal political message. Interestingly, most of the later films pictured a tribal chief or priest who easily believes calumnies and backbites and this character makeup became a trope. This is how the tribal local self government is being represented. There is a typical female character, Kurumatty, a tribal tattooist and a wife, who tries to seduce our tribal hero. An image of 'maneating' sex thirsty woman stereotype is being constructed, leading to another trope. It is reported that a noted south Indian actress Urvasi Sharada was first approached by the director for the role of the heroine, but she refused to do that role for the dressing style suggested by the director, which in her perception, was that of a pleasure object.

In a later film Uyarum nhan nadake (1985) the custom of excommunication for an illegal sexual relationship was well depicted from a nontribal point of view. The protagonist is socially excluded and has been denied most of his fundamental rights as a member of the tribal group. He lives alone in a forest nearby the settlement where his family resides. Here also, the role of the tribal head is suspicious.

\section{PICNIC: THE TOURIST GAZE}

Picnic (1975) another visually rich film directed by J. Sasikumar, which tells the story of a devastated tribal settlement which was evicted to construct a dam. The protagonist was an engineer who comes to the tribal settlement for a survey for constructing a hydropower project and eventually falls in love with the pretty daughter of the adivasi head. The tribal people resist both types of invasions only to be defeated by the governmental agencies. Evergreen superstar Prem Nazir starred as the protagonist and he could easily bag the public support to win both the heroine and the public consent for the development. Actress Lakshmi Narayan, popularly known as Lakshmi, who has an inter-textual experience of winning the hearts of South Indian superstars, is obviously ill-suited in a tribal settlement and thus legitimizes her own abduction as well as the wiping out of the entire community.

The title of the film, Picnic clearly indicates a tourist gaze towards the tribals as they are differently dressed, use colorful indigenous ornaments and sing and dance differently. Sociologist John Urry (2005, p. 3) describes how this tourist gaze stereotypes cultural and racial experiences and reduces them to mere commodity. He argues that films and photographs enable the gaze to be endlessly reproduced and recaptured. Moreover, most of the tribal characters are portrayed by notable villains of the then film industry, which apparently regulates the banishment of the evildoers and smoothens the developmental activities of the governmental forces. A 1972 Hindi film Yeh Gulistan Hamara, directed by Atma Ram had a somewhat similar narrative structure. Sharmila Tagore plays a girl from a tribe in the north-eastern hills, who is part of the gang of an evil local leader. India is worried about its north eastern residents 
who are cut off from the mainland and are generally backward, illiterate and underdeveloped. The government appoints a special officer cum civil engineer to construct a bridge over a river next to the tribal village in the north eastern part of India. On seeing the hero, our tribal heroine falls in love. Fidelity changes and her commitment shifts from her tribal chieftain to the Indian nation. In Malayalam, bridging up a relation with the mainland becomes irrelevant and the process of civilizing the uncivilized takes its place. The tribals protesting for their birthplace and habitual habitat, become traitors and are branded as enemy of the people. Naturally, all of the tribal members were not categorically marked as 'the other', as the beautiful daughters of the earth they are very much acceptable as romantic partners.

This 'daughter of earth' image followed the actress Lakshmi to a couple of films, in which she portrayed the same tribal beauty with splashy costumes with naked shoulders, colorful bangles and necklaces. Ponni, a 1976 film, written and directed by playwright Thoppil Bhasi and adapted from a work by the famous novelist Malayattoor Ramakrishnan, which tells an inter-tribe love story, also develops a touristic gaze towards the untouched virgin landscape. Kamal Haasan, a versatile superstar of Indian film, appeared in the central character and Lakshmi in the eponymous role. The film starts with a tribal arts festival, in which the protagonists could express their various artistic and martial talents. They fall in love with each other, regardless of the difference in community. The film shows the tribal slash-and-burn cultivation methods and a governmental intervention. Tribals are forced to seek some other jobs for their living. Their traditional way of life suddenly becomes anti-social and anti-environmental.

\section{DISPLACED AND DISPOSSESSED}

A 2002 film Bamboo Boys, directed by Ali Akbar turned out to be an ideal example of how the cinematic apparatus represents tribal people. The film tells the story of four tribals from the jungle who come into town in search of a physician to cure their headman's wife and to win the hand of Kuduki, the headman's daughter. Being in a town for the first time, everything seems new and strange for them. They are portrayed as odd men in the civilized world. They are terribly unaware of not only the technological advancement of the outside world but even the minute things outside the jungle. Interestingly, four leading comedians namely Kalabhavan Mani, Harishree Ashokan, Cochin Haneefa and Salim Kumar took the roles. It resembles the 1980 South African comedy film, Gods Must be Crazy in some respects, which tells the interesting story of a tribal bushman, living in a desert, completely ignorant of the world beyond. He once got an unbroken glass coca-cola bottle thrown out of an aeroplane and the tribal people, who see it for the first time, think it as a gift of God and make use of it for almost every purpose. Likewise, the bamboo boys in town see everything anew and they even drink 
water from a toilet commode seen in a modern house. We can see that in these types of slap-stick comedies, the genuine problems which the tribals face are neglected and buried under the laughter and they become more and more voiceless. As depicted in the film poverty and ignorance continue to keep them poorer and less dignified. If they are educated properly, it can easily bring changes and development gradually for the next generation. In Kerala, there are a number of primary schools in several tribal settlements but they are not adequately distributed. The quality of education available to the majority is under question. Forgetting all such things the most popular mass medium, unscrupulously ridicules the entire community through the humour. Moreover, as a category, the referring terms used as tribal or Adivasi actually flatten the vast diversity of minority cultures and identities them into one generic label for the sake of representation.

One of most realistic accounts of tribal situation in Kerala was shot in the film Photographer (2006), a film by Ranjan Pramod, starring Mohanlal in a double role and Master Mani, an Adivasi boy in role resembling his actual life situations. The film was based on the Muthanga Incident which refers to an episode of police firing on the tribal people in the Muthanga village of Wayanad district, Kerala. In 2003, Adivasis assembled under Adivasi Gothra Maha Sabha, one of their organizations, to protest the Government's delay in allotting them land, which had been contracted two years earlier. At some point in the protest, Police fired 18 rounds killing two, including a police officer. Using the real footages of the incident, the film tells the story of a small boy who lost his family in the shooting. He was taken to the town by a wildlife photographer, who was sympathetic towards the tribal people. He was handed over to a tribal school as a hideout from the police who were in search of the boy who is an eyewitness to the brutality. Somehow the protagonist escapes from the police and decides to take the boy home. But the boy, who is displaced from his natural surroundings cannot accommodate to the new urban situation and expresses his wish to go back to the forest.

The film grabbed attention for its serious treatment of tribal life issues such as land and education. As all historical references point out, most of the tribals were originally food gatherers and most of them make a living from the forest. But later, as urbanization blooms, tribals are forced to live in colonies which lack most basic needs. They normally don't destroy the forest or its resources, but could easily be acquainted with the roughest conditions. Cutting a tree for making a hut has become an offence and eventually the colonizer's laws and regulations make them offenders. Most of the developmental activities make the tribals suffer and their natural habitats are wiped out outrageously.

Various studies and reports (Fernandes, 1991; Tukral, 1992; Mathur, 1995) show that tribals have paid the highest price for national development because their regions are resource rich: around $90 \%$ of the coal and around $50 \%$ of other minerals exist in the regions where adivasis live. Water and other sources are abundant in their green habitat. As per statistical records, the tribal people who 
constituted less than $10 \%$ of the total population of India make up 55\% of the total displaced persons by reason of development projects (Mishra, 2002, pp. 197-198). According to the Ministry of Tribal Affairs, Government of India, nearly $8.5 \mathrm{mln}$ tribals were displaced up to 1990 wherefore mega developmental projects like dams, mining, industries and conservation of forests without proper rehabilitation ${ }^{10}$. They were all promised new lands and life situations, but are still dispossessed. Agitations arise from time to time and place to place, but the Governments could easily overcome the pressure using various strategies. The popular films usually engage in a legitimization process, portraying tribals as uncultured drunkards for whom properties such as land or houses will not survive for long.

We have seen the representational pattern circles around a certain set of stock tropes such as a bloodthirsty savage as shown in the film Ponni, an illiterate and uncultured clumsy one as in Bamboo boys. There is another style of representing tribals known as tribal number, in which they sing, dance and enjoy life in a joyful manner being unaware of the complications of life. Actually these kinds of depictions place them as 'other' to the familiar mainstream life situations and thus make them stranger. The song and dance sequences conform a pattern of exotic and sexualized pleasure object and eventually formulate a fetish objectification. Most of the films discussed earlier have more than half of a dozen song and dance sequences, with marvelous musical extravaganza. The first ever tribal film Nellu, arrayed four beautiful songs by Salil Chowdhary including one by bollywood maestro Lata Mangeshkar. Ponni had eight marvelous songs by noted composer Paravoor Devarajan and Uyarum Nhan Nadake have four songs. Even the comedy film Bamboo Boys used eight songs. Some of the songs tried to imitate the tribal dialect, but none used a specific tribal language. These films generally speak official standard Malayalam and tribal characters speak an artificial dialect made exclusively for them which is not spoken by any of the tribal groups in Kerala. There are a number of tribal languages in Kerala but the films never represented any one of them.

However, some of the recent films have tried to rectify these misrepresentations and portray the daily life of Adivasis in a more humane and empathetic manner. Apart from feature films, documentaries like Have You Seen The Arana (Sunanda Bhat, 2012) strive to represent tribal life as a continuous struggle to maintain their unique cultural identity and lifestyles amid dwindling natural resources and the onslaught of globalization. But most of them remain un-popular.

10 "As per the information readily available, a population of 21.3 million have been displaced between 1951 and 1990 in the states of Andhra Pradesh, Bihar, Gujarat, Maharashtra, Madhya Pradesh, Rajasthan and Orissa. Of whom, 8.54 million (40 per cent) are tribals and of those only 2.12 million (24.8 per cent) tribals could be resettled, so far"' (Government of India., 2002, p. 458). 


\section{CONCLUSION}

We have seen in this paper that representational patterns of the filmic apparatus are highly influenced by the dominant ideology and are always constructing images of people, places, beliefs and ideas. This ideological enterprise creates stereotypical images of the various aboriginal groups which are largely distinct and identify themselves with their own mythologies, tales of origin, and distinctive religious and ritualistic practices. The pleasure principles of the cinematic medium generate a tourist gaze towards the aboriginals as they are differently dressed, use indigenous ornaments and sing and dance differently which in effect a stereotype and commodify the distinct cultural and racial experiences. Through the fetishistic and panoptic gaze, the power relation becomes more evident and the spectators identify their position to that of the surveillant though they themselves fall in a position of object to be watched at through the technological apparatus. By analyzing these films it is evident that several methodological and theoretical gaps remain. Further investigations using the theoretical standpoints of imagology, tourist gaze etc. and the integration of various approaches are therefore very important to arrive at clearer explanations.

\section{REFERENCES}

1. Chattopadhyay, S. (2016). Unnatural State: The Changing Representations of Tribal People in Hindi Cinema. Retrieved from: http://www.caravanmagazine.in/essay/unnatural-state-changingrepresentations-tribal-people-hind-cinema.

2. Davis, G. V., Devy, G. N., Chakravarty, K. K. (2014). Performing Identities: Celebrating Indigeneity in the Arts. New Delhi: Routledge India.

3. Fernandes, W. (1991). Power and Powerlessness:Development Projects and Development of the Tribals. Social Action, 41(3). 243-270.

4. Foucault, M. (1979). Discipline and Punish: the Birth of the Prison. New York: Vintage.

5. Government of India. (2002). Tenth Five Year Plan 2002-2007. New Delhi: Planning Commission of India.

6. Guzy, C., Guzy, M. Guzy, L. (eds.). (2014). Voices from the Periphery: Subalternity and Empowerment in India. New Delhi: Routledge India.

7. Hasnain, N. (2002). Tribal India. New Delhi: Palaka Prakashan.

8. Leerssen, J. (2016). Imagology: On using ethnicity to make sense of the world. Retrieved from: http:/ /iberical. paris-sorbonne.fr/wp-content/uploads/2017/02/Pages-from-Iberic@l-no10-automne-2016-Final-2.pdf.

9. Majumdar, D. N. (1961). Races and Cultures of India. Bombay: Asia Publishing House.

10. Mathur, H. M. (1995). The Resettlement of People Displaced by Development Projects Issues and Approaches. In: H. M. Mathur (Ed.). Development, Displacement and Resettlement: Focus on Asian Experiences (pp. 15-38). Delhi: Vikash Publishing House.

11. Mishra, S. K. (2002). Development, Displacement and Rehabilitation of Tribal People: A Case Study of Orissa. Journal of Social Science, 6(3). 197-208.

12. Mulvey, L.(1993). Visual Pleasure and Narrative Cinema. In: B. Nichols (Ed.) Movies and Methods Vol 2 (pp. 305-315). Calcutta: Seagull Books.

13. Pillai, G. N. M. (1970). Malayala Cinema Directory. Kottayam: Commercial Arts Centre

14. Thukral, E.G. (Ed.) (1992). Big Dams Displaced People. New Delhi: Sage Publication.

15. Urry, J. (2005). The Tourist Gaze. London: Sage Publications

16. Vidyarthi, L. P., Rai, B. K. (1985). Tribal Cultures of India. New Delhi: Concept Publishing House.

17. Vijayakumar, B. (2014). Nellu: 1974. Retrieved from: http://www.thehindu.com/features/ cinema/cinema-columns/nellu-1974/article6180555.ece.

18. Von Furer-Haimendorf, Ch. (1982). Tribes of India: The Struggle for Survival. Berkeley: University of California Press. 